POLITYKA ENERGETYCZNA - ENERGY POLICY JOURNAL

$2020 \star$ Volume $23 \leftarrow$ Issue $4 \uparrow 67-90$

DOI: $10.33223 / \mathrm{epj} / 128598$

\title{
Ukraine's energy policy: analysis and development strategy
}

ABSTRACT: The article reveals the problems of the formation and implementation of Ukraine's energy policy from the beginning of its independence to the present day. The specificities of the fuel and energy sector of the country's economy, the main stages of formation, macroeconomic conditions and the problems of its transformation were analyzed. The slow and contradictory processes of reforming Ukraine's fuel and energy complex throughout the period of its independence and the fact that the inconsistency with the main directions of the economic policy did not ensure its effective transformation have been proven. The results of the OECD assessment of progress towards the main objectives implementation of the Ukraine's Energy Strategy have been presented. It was noted that the results of the research suggest that the progress in achieving the goals of Ukraine's Energy Strategy is ambiguous, therefore the strategy needs to be refined accordingly. There are two main factors moving away from the formal and declarative nature of Ukraine's energy policy to its realistic model.

$\checkmark$ Corresponding Author: Kateryna Kuznietsova; e-mail: kuznietsova.k@gmail.com

1 National Technical University of Ukraine „Igor Sikorsky Kyiv Politechnic Institute”, Ukraine; ORCID iD: 0000-0003-0317-8675; e-mail: dergacheva.viktoria@gmail.com

2 National Technical University of Ukraine „Igor Sikorsky Kyiv Politechnic Institute”, Ukraine; ORCID iD: 0000 -0001-5405-0159; e-mail: marina.kravchenko.kpi@gmail.com

3 National Technical University of Ukraine „Igor Sikorsky Kyiv Politechnic Institute”, Ukraine; ORCID iD: 0000-0003-0162-1071; e-mail: kuznietsova.k@gmail.com

4 National Technical University of Ukraine „Igor Sikorsky Kyiv Politechnic Institute”, Ukraine; ORCID iD: 0000-0002-5856-1877; e-mail: tkotsko@gmail.com

2020. The Author(s). This is an open-access article distributed under the terms of the Creative Commons Attribution-ShareAlike International License (CC BY-SA 4.0, http://creativecommons.org/licenses/by-sa/4.0/), which permits use, distribution, and reproduction in any medium, provided that the Article is properly cited. 
Firstly - an international factor associated with Ukraine's extending involvement in international cooperation within the energy sector, Ukraine's international commitments to reform the energy sector towards increasing energy efficiency, green energy, etc. Another - the crisis factor - as a result of the energy policy of the Russian Federation. It was noted that the role of these factors in the future will remain determining. The need to improve Ukraine's energy policy, taking the current trends in the development of the world energy system, new challenges and threats to politico-military and energy confrontation with the Russian Federation into account, has been proven.

KEYWORDS: energy policy, energy strategy, fuel and energy complex, security

\section{Introduction}

Ukraine's energy sector is a complex and branched system of industries that ensure the production, transmission and distribution of fuel and energy resources among different subjects of economic relations. Its effective development is an important prerequisite for ensuring the competitiveness of the country's economic system, strengthening its energy and economic security. Ukraine's energy sector was formed as a part of the USSR energy sector, the main task of which was to serve the industrial model of the economy with cheap energy resources and the absence of environmental restrictions. The significant scale and potential of Ukraine's energy sector turned out to be one of the main problems in the country's transition to a market economy.

This sector reflects the country's enormous opportunities for the implementation of transit potential, increasing energy exports and industrial production, strengthening Ukraine's role in the system of international economic relations. However, its structure, scale and sectoral features significantly complicate the effective transformation towards the transition to market conditions. During the 30 years of independence Ukraine has failed to form effective fuel and energy markets, to significantly increase energy efficiency and to reduce the dependence on the imports of energy resources. Delays of energy reforms make it impossible to move towards high-quality economic growth and to intensify the processes of structural economic transformation. Against the backdrop of intensifying external economic threats, the instability of international fuel and energy markets and significant dependence on energy imports, the accumulation of structural imbalances in the country's fuel and energy sector has hindered the processes of effective economic development strengthening its exogenously oriented model. Thus, the reforming of Ukraine's energy sector is a key factor in the final transition from the post-Soviet planned model of the economic system to the market, which allows to increase its adaptability and opens opportunities for implementing the sustainable development principles.

Considering the role of the fuel and energy complex in the Ukrainian economy, progressive changes in the energy sector should be reviewed in the context of country's energy and economic security. These tasks become especially relevant in terms of economic and politico-military confrontation with the Russian Federation, which until recently was one of the main suppliers 
of energy resources to Ukraine and used energy as an instrument of political pressure (NISD 2018). Strengthening the country's energy security requires solving not only energy efficiency problems, diversification of energy supplies, the fuel and energy balancing, but also problems of optimizing the economic structure - a gradual transition to a post-industrial model.

The fulfillment of the outlined tasks involves the development and implementation of appropriate provisions in the state energy policy. Ukraine has adopted a sufficient number of documents that set out priorities and mechanisms for reforming the energy sector. In practice, the implementation of their provisions was ineffective due to a number of reasons. One of the main reasons was the lack of sustainable economic development, in particular, there were significant fluctuations in economic growth from year to year (from 12.1\% of GDP in 2004 to $-14.8 \%$ in 2009) (SSSU 2020). Other reasons include the inconsistent and contradictory behavior of the state as a subject of energy policy.

Ukraine's cooperation with the EU has become an important progress factor in the field of energy sector reform. Ukraine has made a number of international commitments on reforming its energy sector. The implementation thereof will determine the prospects for further integration into the EU and the support of the country's European integration prospects. In 2010, Ukraine joined the Treaty on establishing the Energy Community, which should be considered the beginning of the implementation of EU legislation in the energy sector (PUA 2010). The Association Agreement between Ukraine and the European Union as of 2014 stipulates the extension of cooperation in the energy sector - Ukraine has committed itself to bringing its national legislation in line with EU legislation, norms and standards and to implement systemic reforms in the energy sector (AAUEU 2015). The ratification of the Paris Agreement on July 14, 2016 on Ukraine's commitment to join the fight against climate change has become an important event (RPA 2016).

Problems of the formation and implementation of the energy policy in Ukraine are presented in many scientific papers. Most scientists and experts positively assess the importance of the strategic approach to energy policy initiated during the development of Ukraine's Energy Strategy until 2030 (ESU 2030), as well as the ideology of the new strategy - Ukraine's Energy Strategy until 2035 "Security, Energy Efficiency, Competitiveness" approved by the Government of Ukraine in 2017 (ESU 2035). However, some scholars emphasize the priority of energy security (Bobrov 2013; Sukhodolia 2017) as one of the important components of the country's economic security. A number of scientists link the priority tasks of energy policy with the need to improve its energy efficiency (Basok and Bazeev 2017; Denisyuk et al. 2016). Many experts draw attention to the importance of developing such a structure of the energy complex, which presents nuclear energy and identifies strategic priorities for its development (Analytical report 2019). Another group of scientists underlines the problems of green energy and the need of forming the preconditions for the transition to a sustainable development model (Barannik 2016; Kharichkov and Krutyakova 2014). In the same context, experts substantiate approaches to the development of non-traditional energy systems (Kudrya 2015). In (Lir 2018). Forming the state energy policy on the principles of national economic pragmatism, taking the priorities of European integration and sustainable development into account is proposed. 
Many works of foreign scientists reveal the conceptual provisions and methodological principles of the formation of the state's strategic energy policy, substantiate approaches to determining strategic priorities in the energy sector, their quantitative formalization and mechanisms for achieving them (ECER 2012; IEA 2012; Krog and Sperling 2019; OECD 2019; SEP 2018; Terrados et al. 2010). Such developments are of great interest to the formation of Ukraine's energy strategy, but there is a need to find a balanced approach to adapting this experience given the specific structure of Ukraine's economy, problems and trends in its economic development, fuel and energy sector, energy and economic integration and the role of the energy component in ensuring the efficiency of country's economic development.

Despite the different emphases of scientists in the vision of the main goals and objectives of energy policy, the dominant opinion is the need of improving it - in order to find responding mechanisms to current energy security threats and new challenges in the world energy system taking into account strategic priorities. In this context, the problem of interdependence between economic transformations and transformations of the energy sector becomes especially relevant and requires appropriate research. For a long time this aspect hasn't received due attention in methodological approaches to energy policy and in the development of certain state-level energy documents, which has been one of the main causes of controversial processes of Ukraine's energy sector transformation.

The development of an effective energy policy is a difficult task in a methodological sense. Ukraine's energy policy should reflect not only a system of priorities and goals, but also respond to current challenges and threats and offer mechanisms for solving specific problems, effectively respond to the trends in the world energy system, taking the priorities of economic structural transformation into account. Its substantiation should be based on forecasts of the country's economic development trends and the understanding of its future economic model. An important task is to ensure the rational integration of energy and economic policy instruments.

\section{Economic conditions and stages of Ukraine's fuel and energy complex transformation}

Analyzing the problems of Ukraine's energy policy it should be noted that the transformation of its energy complex since the early 1990s has taken place in difficult political and economic conditions. Against the backdrop of a significant decline in GDP (in the period from 1990 to 2000 the decline in GDP was over 60\% (SSSU 2020)) the country did not reach a political consensus on maintaining the state's course for market economic transformation. Such a consensus started being reached in the early 2000s with the advent of economic growth. As a result, economic transformations have been extremely slow and controversial. The existing structure of the country's fuel and energy sector at that time was unable to adapt to the new economic conditions. 
In addition, structural imbalances in the system "energy - economy" have intensified. The rupture of economic ties with the former Soviet republics, the constant rise in fuel and energy prices, the destabilizing effects of global economic crises and systemic macroeconomic instability have made it to some extent impossible to formulate and implement an effective energy policy based on strategic planning. At the same time, the decline in industrial production and falling demand for fuel and energy resources by the early 2000s gave hope that the energy sector would fulfill its tasks. The ongoing privatization processes in Ukraine's energy sector have also added optimism.

The first important document about the formation of state energy policy (which was adopted at the state level) was the Resolution of the Parliament of Ukraine "On Ukraine's National Energy Program until 2010" of May 15, 1996 N191 / 96-VR (NEPU 1996). The program was primarily focused on solving the problems of the fuel and energy sector and meeting the needs of the country's economy in all types of fuel and energy. The following documents were: "Energy Strategy of Ukraine until 2030" - approved by the order of the Government of Ukraine dated March 15, 2006 № 145-r (expired due to the approval of the new Energy Strategy dated July 24, 2013 №1071-r) (ESU 2030) and the Energy Strategy of Ukraine for the period up to 2035 “Security, Energy Efficiency, Competitiveness" - approved by the order of the Government of Ukraine dated August 18, 2017 № 605-r (ESU 2035). The adoption of such documents was important for understanding the problems of Ukraine's energy sector development, defining the goals and objectives of energy policy, mechanisms for its implementation, substantiation of the state energy security conceptual foundations. However, none of these strategies have achieved their indicative goals and indicators due to the fact that the implementation of these documents took place in conditions of uncertainty in the development of the Ukrainian economy, international energy markets and the world economy as a whole. In addition, it should be noted that in organizational and economic terms the country was not ready to implement these strategies. The demarcation between economic and energy reforms, the non-transparent privatization of energy enterprises and, as a consequence, the strengthening of the financial and industrial groups influence on public administration processes and the growth of macroeconomic instability made the real progress in the energy sector impossible.

There are three conditional stages of Ukraine's energy complex transformation, which will ensure a better understanding of the problems of state energy policy as a whole (Table 1). The analysis of the energy sector transformation should be carried out taking the peculiarities of macroeconomic dynamics into account. Quite a strong interdependence of energy economic factors in the processes of macroeconomic transformations, to some extent explains the low efficiency of state energy policy at different stages of its economic development.

Analyzing the above stages of Ukraine's energy complex transformation, it should be noted that during the first stage (1991-1999) there was an inertial restructuring of the energy complex under the influence of the transformation crisis associated with the transition to a market economy model. During this period there was a significant decline in production in the energy sector, a significant increase in prices, and as a result - limited resource opportunities for enterprise development. During the second stage (2000-2013), the problems of energy complex development did not acquire strategic priorities in the public policy system given the positive 
TABLE 1. The main stages of Ukraine's energy complex transformation

TABELA 1. Główne etapy transformacji kompleksu energetycznego Ukrainy

\begin{tabular}{|c|c|c|c|}
\hline Stages & $\begin{array}{c}\text { Problems of macroeconomic } \\
\text { development }\end{array}$ & $\begin{array}{c}\text { Problems of energy complex } \\
\text { development }\end{array}$ & Features of energy policy \\
\hline 1 & 2 & 3 & 4 \\
\hline $\begin{array}{l}1991- \\
-1999\end{array}$ & $\begin{array}{l}\text { The period is characterized by } \\
\text { a significant decline in GDP } \\
\text { (in } 1999 \text { a decline over } 60 \% \text { of } \\
\text { GDP compared to } 1991 \text { (SSSU } \\
\text { 2020)), the rupture and restruc- } \\
\text { turing of economic relations of } \\
\text { industrial enterprises, a signifi- } \\
\text { cant increase in fuel and energy } \\
\text { prices and inflation in general, } \\
\text { a critical growing problem of } \\
\text { economic entities solvency }\end{array}$ & $\begin{array}{l}\text { Significant and rapid increase in } \\
\text { energy prices and energy resources; } \\
\text { exacerbation of problems with fuel } \\
\text { and energy resources; increasing } \\
\text { threats to energy security due to } \\
\text { significant dependence on energy } \\
\text { imports from the Russian Federa- } \\
\text { tion and limited solvency of fuel } \\
\text { and energy resources consumers; } \\
\text { imbalance between the prices of the } \\
\text { energy and fuel sectors' products and } \\
\text { the costs for their production; incon- } \\
\text { sistency of prices for fuel and energy } \\
\text { resources with costs; accumulation } \\
\text { of debt problems of the fuel and } \\
\text { energy complex enterprises, accele- } \\
\text { ration of assets depreciation; signifi- } \\
\text { cant increase of the production costs } \\
\text { in the energy and fuel sectors }\end{array}$ & $\begin{array}{l}\text { Lack of a strategically oriented } \\
\text { approach in managing the fuel } \\
\text { and energy complex; dominance } \\
\text { of the operational management } \\
\text { model; the main task of state } \\
\text { policy is to form the necessary } \\
\text { supply of energy and fuel for the } \\
\text { needs of the economy; ignoring } \\
\text { the system of barter settlements } \\
\text { and mechanisms of intersectoral } \\
\text { subsidies and as a result, incre- } \\
\text { asing structural imbalances in } \\
\text { the field of pricing; the begin- } \\
\text { ning of privatization processes } \\
\text { in the energy sector, which were } \\
\text { characterized by non-transparen- } \\
\text { cy and lack of mechanisms to } \\
\text { attract strategic investors }\end{array}$ \\
\hline $\begin{array}{l}2000- \\
-2013\end{array}$ & $\begin{array}{l}\text { There are two stages: the pe- } \\
\text { riod of economic recovery after } \\
\text { adeepandlong-termcrisis: } 2000- \\
-2008 \text {, and the period of eco- } \\
\text { nomic crisis: the end of } 2008- \\
-2010 \text {. } \\
\text { Transition to economic growth- } \\
\text { from } 2000 \text { to } 2008 \text { (in } 2000 \text { for } \\
\text { the first time there was a positi- } \\
\text { ve GDP growth }-2.2 \% \text {, in } 2004 \\
\text { GDP growth reached } 12.2 \% \\
\text { (SSSU 2020)), however, there } \\
\text { was a significant dependence of } \\
\text { the state economic development } \\
\text { from the foreign commodity mar- } \\
\text { kets, the state was dominated by } \\
\text { a policy of stimulating demand }\end{array}$ & $\begin{array}{l}\text { Intensification of contradictions in } \\
\text { the energy sphere with the Russian } \\
\text { Federation; critical aggravation of } \\
\text { natural gas supply problems to Ukra- } \\
\text { ine, growth of its cost. } \\
\text { Exacerbation of the problems of } \\
\text { thermal energy enterprises economic } \\
\text { stability, the presence of a steady } \\
\text { tendency to increase the cost of ener- } \\
\text { gy and fuel, strengthening the role of } \\
\text { the energy component in the cost of } \\
\text { industrial production. } \\
\text { Chronic deficit of investment resour- } \\
\text { ces of energy entities, acceleration of } \\
\text { the processes of moral and physical } \\
\text { deterioration of their production as- } \\
\text { sets }\end{array}$ & $\begin{array}{l}\text { Transition to a system of cash } \\
\text { settlements between producers } \\
\text { and consumers of fuel and ener- } \\
\text { gy resources; policy of develop- } \\
\text { ment of more transparent me- } \\
\text { chanisms of mutual relations in } \\
\text { energy sector; formation of fuel } \\
\text { and energy markets; continu- } \\
\text { ation of privatization processes } \\
\text { in the energy sector and the in- } \\
\text { dustrial complex as a whole; } \\
\text { transition to a strategic approach } \\
\text { in managing the development } \\
\text { of the fuel and energy complex } \\
\text { (Energy Strategy until 2020 } \\
\text { from } 2006 \text { and from 2013) }\end{array}$ \\
\hline $\begin{array}{l}2014- \\
-2020\end{array}$ & $\begin{array}{l}\text { With the beginning of the Rus- } \\
\text { sian-Ukrainian war in } 2014 \text { as } \\
\text { a result of the loss of part of } \\
\text { the territory in the East of the } \\
\text { country, the Crimean peninsu- } \\
\text { la, as well as intensification of } \\
\text { economic confrontation between } \\
\text { countries, there was a significant }\end{array}$ & $\begin{array}{l}\text { Energy confrontation with the Rus- } \\
\text { sian Federation; partial loss of poten- } \\
\text { tial of the fuel and energy complex } \\
\text { in some regions in eastern Ukraine } \\
\text { (territories not under the control of } \\
\text { Ukraine), first of all coal mining en- } \\
\text { terprises; critical aggravation of pro- } \\
\text { blems of natural gas and coal supply }\end{array}$ & $\begin{array}{l}\text { A radical change in approaches } \\
\text { to the formation and implemen- } \\
\text { tation of the state energy poli- } \\
\text { cy (first of all, the transition to } \\
\text { a market pricing system for fuel } \\
\text { and energy resources); change } \\
\text { in the system of natural gas im- } \\
\text { ports, which reduced the depen- }\end{array}$ \\
\hline
\end{tabular}




\begin{tabular}{|c|c|c|c|}
\hline 1 & 2 & 3 & 4 \\
\hline $\begin{array}{l}2014- \\
-2020\end{array}$ & $\begin{array}{l}\text { decline in real GDP [2]: } 2014- \\
6.6 \% \text { by previous year, } 2015- \\
9.8 \% \text {, while the trend of econo- } \\
\text { mic slowdown was observed be- } \\
\text { fore (SSSU } 2020 \text { ) - year } 2013 \text { - } \\
\text { a real GDP growth compared to } \\
\text { the previous year was zero, in } \\
2012 \text { the growth was only } 0.2 \% \text {. } \\
\text { Since } 2016 \text {, due to the transition } \\
\text { to real reforms, it has been possi- } \\
\text { ble to ensure economic growth - } \\
\text { from } 2.4 \% \text { in } 2016 \text { to } 3.2 \% \text { in } \\
2019 \text {. }\end{array}$ & $\begin{array}{l}\text { to Ukraine; reduction of prospects } \\
\text { for the implementation of the coun- } \\
\text { try's transit potential, investment and } \\
\text { innovation potential of nuclear ener- } \\
\text { gy development. Transition to a mar- } \\
\text { ket approach in the field of pricing } \\
\text { and rising prices in the energy sector. }\end{array}$ & $\begin{array}{l}\text { dence of supplies on the Rus- } \\
\text { sian Federation; development } \\
\text { of a new Energy Strategy until } \\
2035 \text { (the main goal is to ensure } \\
\text { energy and environmental secu- } \\
\text { rity); significant intensification } \\
\text { of energy cooperation with the } \\
\text { EU; start of work on improving } \\
\text { energy policy taking into acco- } \\
\text { unt the priorities of green energy, } \\
\text { the transition to a model of susta- } \\
\text { inable development; formation } \\
\text { of the Concept of "green" energy } \\
\text { transition of Ukraine until } 2050 \text {. }\end{array}$ \\
\hline
\end{tabular}

trends in macroeconomic dynamics (from 2000 to the end of 2008) and the processes of private ownership in the energy sector. At the same time, the positive macroeconomic dynamics did not contribute to strengthening the economic stability of enterprises, the development of their competitive potential. This stage is a period of formation of huge potential for threats towards the state energy security. The third stage (2014-2020) can be characterized as a period of transition to real reforms and effective cooperation between Ukraine and European partners in the energy sector. Despite the aggravation of the crisis in the economy and the critical escalation of threats to state energy and economic security due to politico-military and energy confrontation with the Russian Federation, this period proved to be the most effective in reforming the energy sector.

The country's fuel and energy complex operates in fundamentally new conditions, which significantly offset threats of both an economic and foreign policy nature. There have been significant changes towards transition to market pricing for fuel and energy and towards diversification of energy imports. The development of market participants' investment potential has intensified significantly. The motivation for finding solutions to improve the energy efficiency of production in the industrial complex has increased. At the same time, the issues of transparency in decision -making in export-import operations, pricing and antitrust regulation remain problematic.

\section{Features of Ukraine's energy policy and problems of the fuel and energy complex transformation}

The energy complex of modern Ukraine was formed in the twentieth century within a planned economy. As a result of the state's industrial and energy policy aiming to develop an industrial model of the economic system and build a single economic complex of the USSR, it was focused 
on oil, natural gas, coal and nuclear fuel production. As a part of the USSR, Ukraine, occupying $3 \%$ of the territory and having $1 / 5$ of the population, by 1991 produced more than $1 / 3$ of all-Union production of rolled ferrous metals and steel pipes, almost $1 / 2$ of total ore production (Kislyy and Trofimenko 2002). However, it held a leading position in the USSR only in the extraction of raw materials - extensive development was dominant. The economic model of the country had a pronounced industrial nature. For example, as of 1980, Ukraine was ranked $4^{\text {th }}$ in Europe and $8^{\text {th }}$ in the world in terms of electricity production, $3^{\text {rd }}$ in Europe and $5^{\text {th }}$ in the world in terms of coal production (in terms of conventional fuel), and $2^{\text {nd }}$ place in Europe and $4^{\text {th }}$ place in the world in terms of natural gas production (Zubets' and Panasyuk 2004).

These features of the Ukraine's economic model have led to its significant energy intensity (Fig. 1,2). During the transition to market pricing the energy intensity of the economy was one of the main problems of transformation of the energy sector. The energy intensity of Ukraine's economy significantly exceeds similar indicators of the world's leading countries and significantly limits the opportunities for its competitive development.

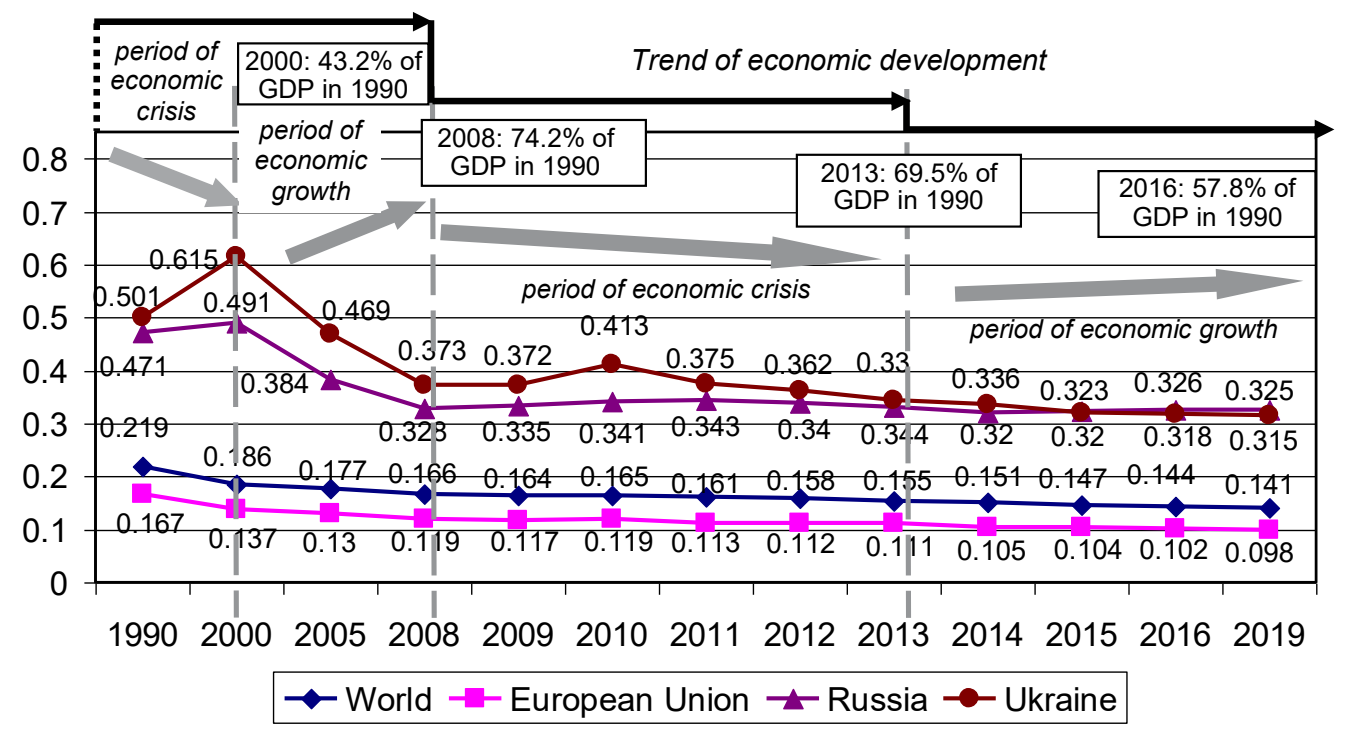

Fig. 1. Economic development trends and energy intensity dynamics of GDP [kg of oil eqv./USD] 2005 (PPP), 1990-2019

Source: (NPCR of the UES of Ukraine 2018; SSSU 2020)

Rys. 1. Trendy rozwoju gospodarczego i dynamika energochłonności PKB [kg ekwiwalentu ropy naftowej/USD] 2005 (PPP), 1990-2019

The data of Figures 1, 2 indicates that the approximation of the energy intensity of Ukraine's GDP to the world average would reduce energy consumption by over half - by 50 million toe. However, such shifts in the energy intensity cannot be achieved only through an energy efficiency policy - an important task is to transform the structure of industrial production. Stimulating 


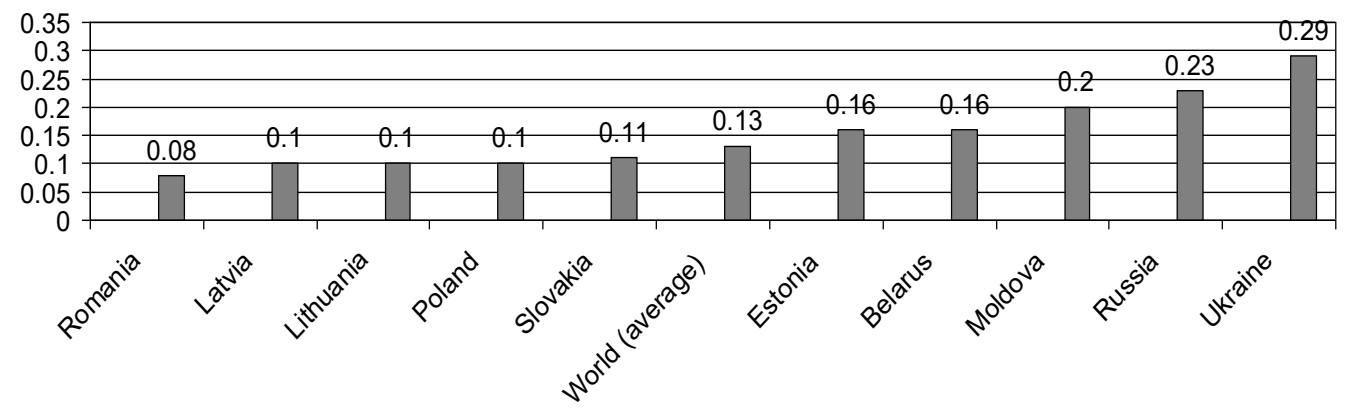

Fig. 2. Energy intensity of individual economies in 2015 [ $\mathrm{kg}$ of oil equivalent/USD] (GDP at purchasing power parity) in 2010 prices Source: (EESU 2018)

Rys. 2. Energochłonność poszczególnych gospodarek w 2015 [kg ekwiwalentu ropy naftowej/USD]

(PKB według parytetu siły nabywczej) w cenach 2010 roku

economic growth within the existing economic structure will not allow to fully realize the potential of energy efficiency and make progress towards the transition to a model of sustainable development. Such dynamics of economic growth will be accompanied by the formation of threats to the state economic and energy security, will provoke crises in the economy and strengthen its energy-intensive structure. The very trends of the country's economic development were observed in the period of 2000-2008.

Ukraine's energy strategy until 2035 sets the task of reducing the energy intensity of GDP more than double - from the current USD 0.28 toe/thousand to 0.13 (GDP per capita) (ESU 2035). At the same time, the following structural changes are envisaged: increasing the segment of industries that are characterized by lower energy intensity of products in the structure of GDP (engineering, light industry, etc.), development of services, intensification of investment processes and modernization of production assets of energy enterprises, the systematic implementation of energy efficiency projects aimed at improving energy efficiency in various areas of economic activity, regional programs for the modernization of the municipal heat and power system.

Structural changes in the economy and energy efficiency are key factors to reducing the energy intensity of production. Ukraine's energy-intensive economy, in conditions of significant dependence on energy imports - primarily natural gas, limits the competitiveness of the economy, complicates the transformation of its structure and energy complex. The high energy intensity of the country's economy is primarily caused by its structural features and the dominance of basic energy-intensive industries. Since a full-fledged market of energy resources was not formed, there were disparities in the formation of prices for fuel and energy resources and monopolies kept a significant influence, the country failed to reduce the energy intensity of production for many years. These circumstances made it impossible to intensify investment processes in the economy, including in the energy sector, as a result - the physical and moral depreciation of production assets crossed critical limits. The structure of the economy, as well as the energy sector, has not undergone qualitative changes. 
Thus, the main features of Ukraine's energy system include: significant energy intensity of production (2 times higher than the world average) (EESU 2018), high energy dependence on energy imports (1/3 of primary energy) (MEU 2020), large losses in energy transportation to the consumer (44\% of energy is lost during conversion and transportation to the final consumer, for example in the EU this figure equals 32\%) (EESU 2018), as well as a significant depreciation of energy enterprises' equipment - over 65\% (according to NJSC "Energy Company of Ukraine" the coefficient of wear is $75 \%$, along with this $90 \%$ of thermal power enterprises have exhausted their estimated service life -100 thousand hours, and $51 \%$ have developed an acceptable limit of physical wear (in world practice) - 200 thousand hours) (Mel'nyk 2015), a significant negative impact on the environment (carbon content of GDP exceeds the same indicator in Poland by 1.8 times, Germany - by 2.8 times and 2.1 times - world level) (NPCR of the UES of Ukraine 2018). This set of problems allows us to understand the low adaptability of the fuel and energy spheres of Ukraine, the peculiarities of the interaction of energy and economic factors in the processes of macroeconomic transformation, and then - the complexity of the energy sector transformation in the transition to a market model. The above problems are systematized in Figure 3.

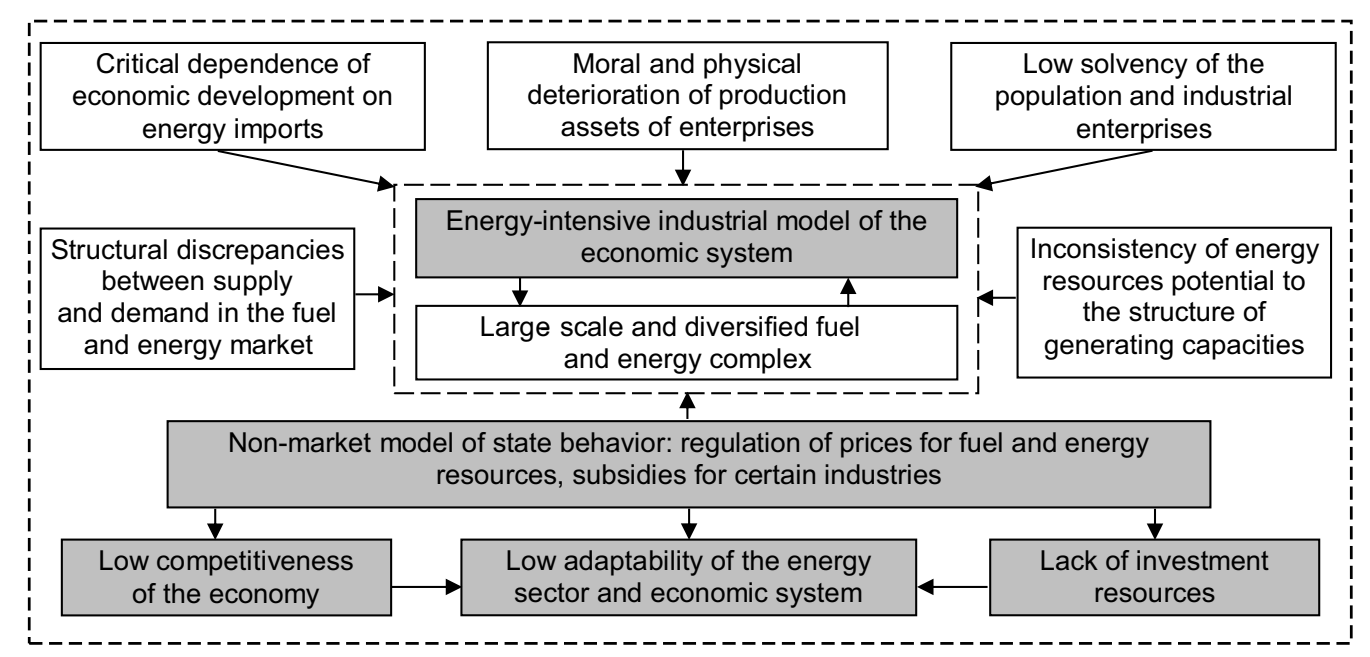

Fig. 3. The problems of Ukraine's energy sector transformation

Rys. 3. Problemy transformacji energetyki na Ukrainie

Figure 3 highlights the role of the state as a subject of energy policy. The attention is focused on the non-market aspects of the state behavior model. Along with the economic instruments of the energy policy (privatization of enterprises, the introduction of market relations between the energy sector, market pricing mechanisms), the state regulated the prices of fuel and energy resources, subsidized certain energy sectors, weakened competitive energy mechanisms markets for a long time. Such measures limited the opportunities for enterprises development and minimized the effectiveness of energy policy. 
Given the specifics of the energy-economic factors' integration in the structure of the country's economy, the problems of transformation of the fuel and energy complex should be considered primarily through the lens of optimization and progressive development of its structure. Unlike many other countries, in the early 1990s there was a combination of many unfavorable factors and preconditions in Ukraine which significantly hindered the progress in reforming both the energy sector and the economy in general.

The system imbalance of the USSR's fuel and energy complex, which included the Ukraine's fuel and energy complex, led to the disproportion increase between the needs for fuel and energy resources and their supply. Another important problem was the significant price increase in the energy sector, physical and moral depreciation of the industrial complex production assets and the lack of investment capital for their modernization. As a result, the competitiveness of Ukrainian products, their solvency and investment opportunities significantly decreased. Delays of the real reforms and attempts to minimize fuel and energy prices in any way, ignoring the strategic security priorities for energy and economic components, led to the formation of a closed cycle of degradation in the country's industrial, fuel and energy complex.

The energy intensity and imbalance of the Ukrainian economy (which is related to its structural features, including the dominance of raw materials, the lack of a domestic market and the large scale of the fuel and energy sector) are those problems of the country's economic model, which significantly distinguish its economy from the economies of other post-socialist countries. The lack of basic preconditions for long-term and high-quality economic growth in Ukraine and (as a result) a procyclical model of economic development made the effective transformations in the energy sector impossible. Under such conditions, the strategic orientation of energy policy lost its role, because its target parameters, for objective reasons, could not be achieved. That is why some strategic legislative and regulatory acts have been proved ineffective.

The main problem of forming an effective energy strategy in Ukraine is the inconsistency of economic and energy policies and the lack of a systematic approach to their implementation. These principles have been ignored for a long time. Partial implementation of the market relations principles in energy and other industries was a generative factor of destructive processes in the economic system in general. It was obvious that it is impossible to ensure transformation in such a large-scale energy sector of Ukraine without the coordination in time of certain instruments of energy and economic policy. Without creating the basic conditions that determine the integrity of the model of the market economic system, the market-oriented steps in the energy sector will further on generate manifestations of destabilizing factors. Thus, the negative trends in the fuel and energy sector are the result of the long absence of a full-fledged model of the entire market economic system and, in particular, energy and fuel markets.

The financial weakness of economic entities and the limited level of their solvency as consumers of fuel and energy resources is a logical consequence of the extremely long and controversial process of market mechanisms' introduction into the country's economy. Under such conditions, the focus on the implementation of the energy policy's modern priorities, which are 
related to its greening, implementation of modern technologies, development of non-traditional energy systems is not just a set of difficulties, but also poses certain threats in terms of the efficiency of use of certain resources. The low diversification of Ukraine's economy, deep imbalances in its structure and close dependence on the foreign raw material markets have determined the pro-cyclical nature of the country's economic development and turned energy into a tool to compensate economic entities through non-market pricing mechanisms for fuel and energy resources, subsidies and the administrative redistribution of financial resources. The energy sector has often been used as a resource to implement the priorities of crisis management during an economic downturn. That is, quite often tactical steps in the framework of energy policy contradicted the strategic priorities defined in regulations. A similar situation was observed even after 2015, when under the pressure of external circumstances the country managed to achieve significant changes in the area of energy security (complete abandonment of imported natural gas from the Russian Federation, diversification of coal supply sources).

A long-lasting privatization process in the energy and other economy sectors has led to additional problems - attempts of some financial and industrial groups to take control over state -owned energy companies and through the shadow mechanisms to lobby their own business interests at the expense of state-owned enterprises. This situation made it even more impossible to attract strategic investors and foreign capital to Ukraine's fuel and energy sector, without which it was impossible to ensure transformation in such a large-scale sphere as the energy sector.

The above mentioned problems explain the fact that the shortage of own energy resources was not a factor of stimulating energy efficiency, the modernization of production assets and restructuring the economy towards the development of industries that produce final products. Paradoxically, an important goal of the government's energy policy for many years was the need to reduce prices for imported energy resources, which essentially contradicted the strategic priorities of the fuel and energy sector and the principles of market-oriented approach to its reform. As a result, real changes in this area have been systematically postponed for an indefinite time, whereas the accumulation of structural imbalances in the intersectoral and investment spheres significantly intensified (Fig. 4).

It is impossible to solve the problems of energy security in the country without changing the structure of the economy, developing a competitive environment and depoliticizing the energy sector. Unfortunately, the precondition for progressive changes in the country's energy sector remains the need to complete the process of forming the basic institutions of the market model of the economic system as a defining prerequisite for launching sustainable mechanisms for its self-development.

In order to understand the scale of the Ukraine's energy complex (inherited from the USSR), attention should be paid to the dynamics of electricity production and production of fuel and energy resources in comparison to 1990 (Fig. 4). Electricity production in the period from 1990 to 2019 decreased almost two fold - from 298.5 million kWh of electricity to 153.9 million kWh (MEU 2020). At the same time, the capacity of power generating enterprises of Ukraine's energy system in 1990 amounted to 55.6 million $\mathrm{kW}$, and in 2019-51.39 million $\mathrm{kW}$ (MEU 2020). That is, the consumption of the power system varied within $30 \%$. 


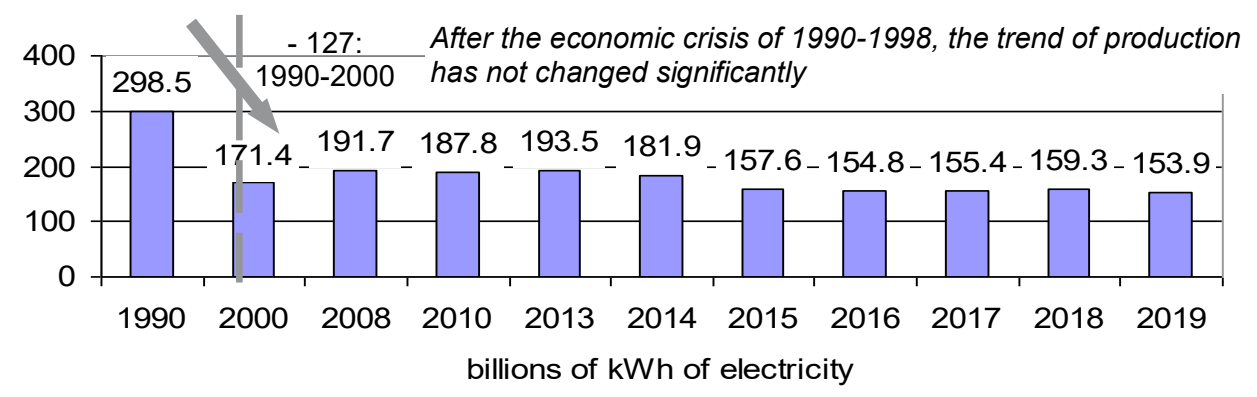

- 6.4: The trend of natural gas production after 1998 has not
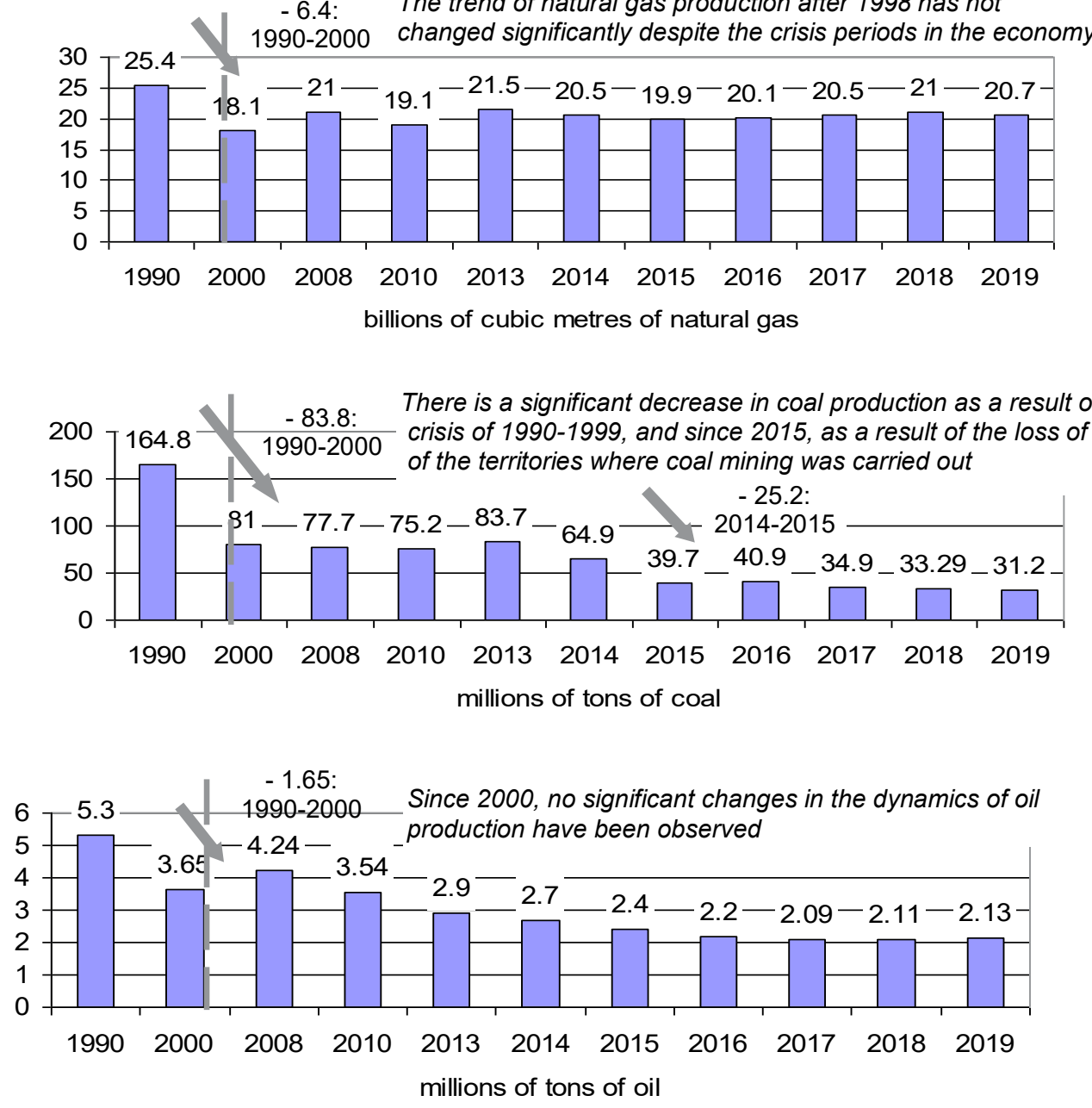

Fig. 4. Dynamics of electricity production, natural gas, coal and oil in Ukraine, 1990-2019 Source: (SSSU 2020; MEU 2020)

Rys. 4. Dynamika produkcji energii elektrycznej, gazu ziemnego, węgla i ropy naftowej na Ukrainie w latach 1990-2019 
The structure of electricity production underwent some positive changes compared to 1990 (Fig. 5), in particular the renewable energy sources were introduced $-3.6 \%$ as of 2019 and the share of hydropower was increased (including storage) - from $4 \%$ up to $5.2 \%$ (SSSU 2020).
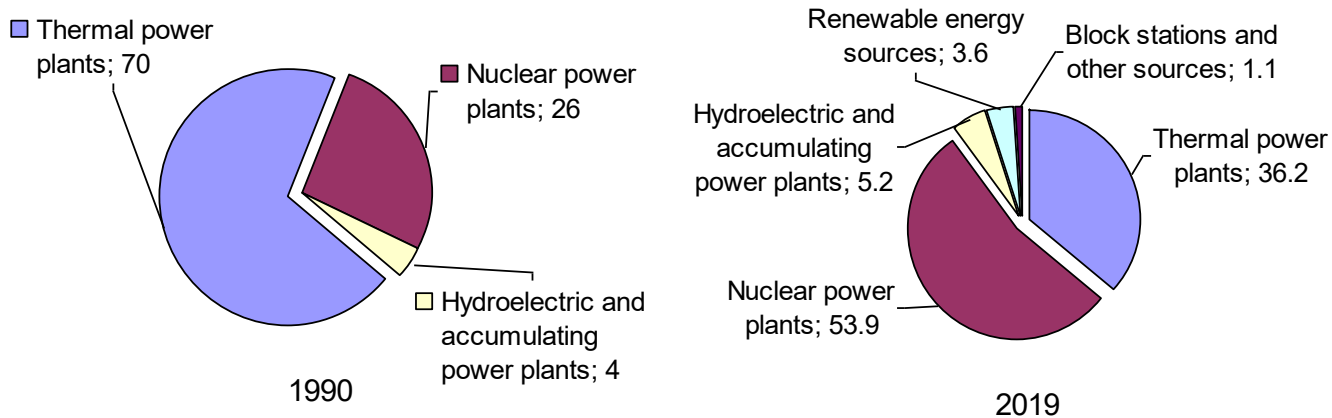

Fig. 5. The structure of electricity production in Ukraine's integrated energy system by generation sources [\%],
1990-2019
Source: (SSSU 2020)

Rys. 5. Struktura produkcji energii elektrycznej w zintegrowanym systemie energetycznym Ukrainy według źródeł wytwarzania [\%], 1990-2019

A decrease in the share of thermal generation, as well as an increase nuclear component are also worth noting. At the same time, these changes took place primarily under the influence of objective factors related to the reduction of industrial production compared to 1990 , economic fluctuations in the period after 2000 and the corresponding transformation of the country's energy system, as well as due to energy pressure of the Russian Federation.

An important criterion for the effectiveness of the policy in the country's energy sector is the structure of the energy balance and the features of its change, in particular - changes in the overall primary energy supply and final consumption. In Figure 6 the main proportions of the Ukraine's energy balance in 2010 and 2018 are shown (SSSU 2020). In 2010, the total supply of primary energy amounted to 132.3 thousand toe, and final consumption -74.0 thousand toe, in $2018-93.165$ thousand toe and 51,171 thousand toe accordingly. Losses in energy conversion and transportation in 2010 reached $44.1 \%$, and in $2018-45.1 \%$, that is no positive changes actually took place, while in the EU this figure was approximately $30 \%$.

It is also important to draw attention to the ratio of supply and consumption proportions for individual components. The main sources of primary energy supply in 2018 were (SSSU 2020): coal $(29.6 \%)$, natural gas $(27.5 \%)$ and nuclear energy $(23.7 \%)$. The positive aspect was a decrease in the share of natural gas in the structure of total primary energy supply from $41.74 \%$ in 2010 to $27.54 \%$ in 2018, as most of it was imported. At the same time, such important components as hydropower, wind, solar energy and biofuels did not undergo significant changes.

The household sector and industry remained the largest energy consumer in $2018-16.2$ million toe (31.6\%) and 16.5 million toe (32.2\%) respectively (SSSU 2020). According to experts, 


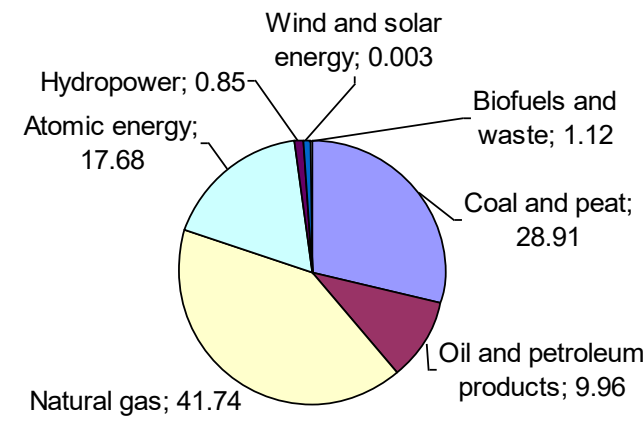

a) Total supply of primary energy, $\%, 2010$

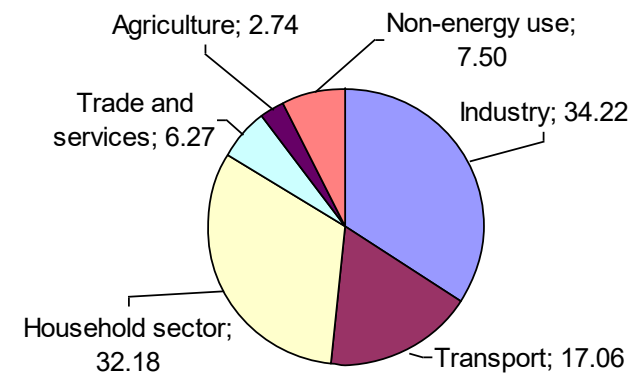

c) Final consumption, \%, 2010

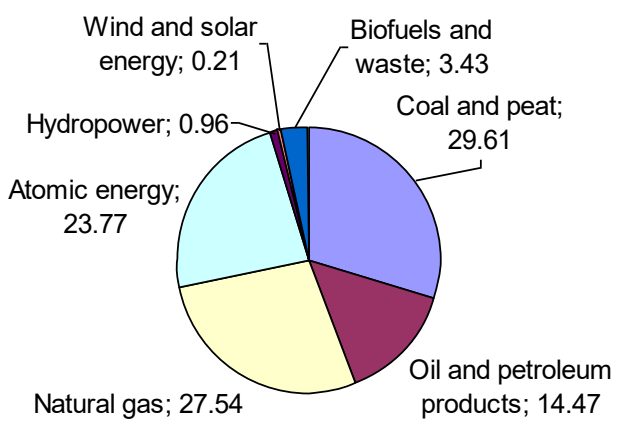

b) Total supply of primary energy, \%, 2018

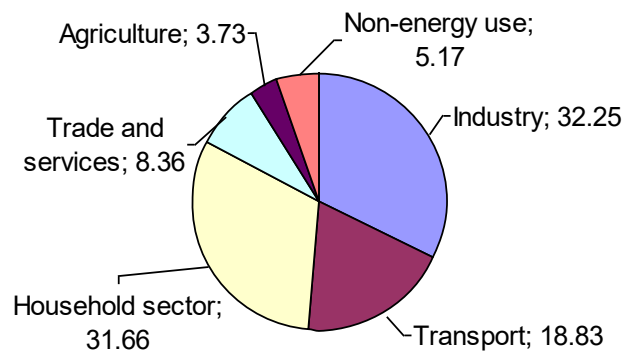

d) Final consumption, \%, 2018

Fig. 6. Energy balance of Ukraine, 2010-2018: total supply of primary energy (a, b), final consumption (c, d) Source: (SSSU 2020; MEU 2020)

Rys. 6. Bilans energetyczny Ukrainy w latach 2010-2018: całkowita podaż energii pierwotnej (a, b), zużycie końcowe (c, d)

Ukraine's commitment to achieve a 9\% reduction in energy consumption by 2020 compared to 2005-2009 was met in 2013, however not through energy efficiency policies, but due to the economic downturn in the country (from 2008 to in 2016, real GDP decreased over 19.5\%) and the loss of control over part of the country (EESU 2018).

There are currently no relevant grounds to predict the intensification of the factors that would provide significant changes in the sphere of energy efficiency and a reduction of primary energy consumption in the medium term.

An important characteristic of Ukraine's energy sector is the presence of a huge potential for energy savings. According to the Commission for State Regulation of Energy, the overall energy saving potential in Ukraine constitutes over $45 \%$ of the consumed fuel and energy resources (NCSREU 2020). An assessment of the energy saving potential conducted in 1997 from the level of the base year 1990 (353 tef) showed that its size amounts to 145-170 million tef (Denisyuk et al. 2016). 
Energy saving priorities have been identified in a number of government documents, including the Energy Strategy until 2030. However, no significant progress has been made in this area. The implementation of energy saving potential, account the peculiarities of Ukraine's energy sector and the model of the economic system taking into, is one of the most important issues in energy security. Its solution is impossible without the creation of real markets for fuel and energy resources, the intensification of investment processes and the optimization of the structural proportions of the economy.

Ukraine's energy sector is characterized by a significant negative impact on the environment. It should be noted that this feature is an expression of the industrial model of the economy as a whole. Thus, until the early 1990s, the annual loss of gross national product due to environmental pollution was over 15-20\% (economic damage from environmental pollution in the EU is estimated at 3-5\% of GDP) (Kislyy and Trofimenko 2002). The energy enterprises were the main polluters - the share of pollution of energy enterprises amounted over $30 \%$, coal mining enterprises $-10 \%$, chemical and petrochemical enterprises $-7 \%$. During 1990-2016, the intensity of $\mathrm{CO}_{2}$ emissions from fossil fuel combustion in Ukraine decreased almost twice, but the carbon intensity of Ukraine's GDP is 1.8 times higher than in Poland, 2.8 times higher than in Germany and 2.1 times higher than in the world (NPCR of the UES of Ukraine 2018).

Today, the energy sector continues to be a major polluter of the environment. This situation is caused not only by its scale and structure, but also the critical depreciation of production assets of enterprises and irrational proportions of the country's energy balance. In addition, no corresponding changes occurred in the sectoral structure of production over the last two decades. The environmental policy did not ensure the implementation of environmentally-oriented priorities of fuel and energy enterprises. For a long time the system of environmental payments was considered as a limiting factor in their development. Today, the environmental component of Ukraine's energy policy is of particular importance given the number of the country's international obligations and is one of the reasons for the need to improve its Energy Strategy.

\section{Efficiency of Ukraine's energy policy and priorities for its improvement}

Table 2 represents the results of the OECD assessment of progress towards the main objectives implementation of the Ukraine's Energy Strategy for the period up to 2035 (adopted in 2017) (OECD monitoring 2035). To increase the effectiveness of Ukraine's Energy Strategy, the OECD has developed a program that allows a comprehensive monitoring of Ukraine's Energy Strategy based on an assessment of 119 indicators and 344 sub-indicators. These results were officially presented in early 2019 , which allows to use them in order to make appropriate adjustments directly to the State Energy Strategy, as well as to improve the policy of the strategy as it 
is currently being revised. The new Strategy will take not only the shortcomings of the previous one, but also the priorities of the Concept of "green" energy transition of Ukraine until 2050 and the provisions of the National Plan for Energy and Climate until 2030 into account. One of the important tasks of the future Strategy is to ensure the fulfillment of Ukraine's international obligations in the energy sphere.

TABLE 2. The results of the progress evaluation in implementation of Ukraine's Energy Strategy until 2035, according to OECD estimates

TABELA 2. Wyniki oceny postępów w realizacji Strategii Energetycznej Ukrainy do 2035 roku według szacunków OECD

\begin{tabular}{|c|c|c|c|c|c|c|c|c|}
\hline \multirow[b]{2}{*}{ № } & \multirow[b]{2}{*}{ Subsectors of energy } & \multicolumn{7}{|c|}{ Objectives } \\
\hline & & 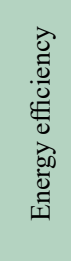 & 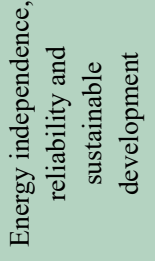 & 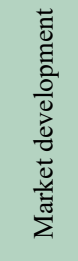 & 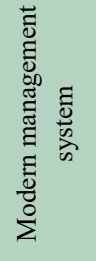 & 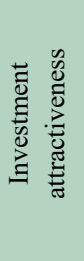 & 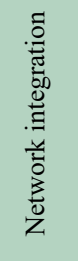 & 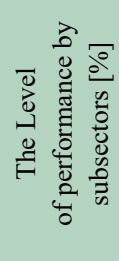 \\
\hline 1. & Coal industry & 2.67 & 2.33 & 1.16 & 1.8 & - & - & 39.8 \\
\hline 2. & Electricity & 1.14 & 2.4 & 3.74 & 5 & 2.8 & 3.34 & 61.4 \\
\hline 3. & Environment and climate & 3 & 2.13 & 2.34 & 2.67 & 1 & - & 44.5 \\
\hline 4. & Heat supply & 3.34 & 1.74 & 3.43 & 1.67 & 1 & - & 44.7 \\
\hline 5. & Natural gas & 3 & 2.91 & 2.83 & 4 & 2.8 & 3.5 & 63.5 \\
\hline 6. & Nuclear energy & - & 2.87 & - & - & - & - & 57.4 \\
\hline 7. & Oil & 1 & 2 & 2.34 & 2.75 & 1.5 & 2 & 38.6 \\
\hline 8. & Renewable energy sources & 3.14 & - & 3 & 0 & 4 & - & 50.7 \\
\hline 9. & $\begin{array}{l}\text { Sectoral supervision and } \\
\text { management }\end{array}$ & 2.7 & 2.5 & 3 & 2.3 & 3 & 1 & 48.3 \\
\hline \multicolumn{2}{|c|}{$\begin{array}{l}\text { The level of performance } \\
\text { by objectives [\%] }\end{array}$} & 49.7 & 47.2 & 54.6 & 50.5 & 37.4 & 49.2 & \\
\hline
\end{tabular}

Note: systematized and calculated based on (OECD monitoring 2035).

Table 2 contains the average values of the implementation of the system of goals of the Energy Strategy (efficiency; independence, reliability, sustainable development; market development; management system; attractiveness for investment; network integration) for 9 subsectors of energy. A range from 1 to 5 is used to assess the level of achievement of goals on a scale from "not started" to "completed". The results of the research suggest that the progress in achieving the goals of Ukraine's Energy Strategy is ambiguous, therefore the strategy needs to be refined accordingly. Analysis of the data in Table 2 confirms the greatest progress in such goals as "Market Development" (54.6\%) and the "Modern Management System" (50.5\%). In general, the 
implementation of these goals is at an intermediate stage, while the implementation of the system of other goals is at an early stage. With regard to the sub-sectoral level, experts note a certain heterogeneity in the dynamics of values, although the least progress is observed in the oil and coal industries.

It is worth paying attention to the investment component in the system of energy policy goals as it is integrated, indicates the level of institutional change in the energy sector, the economy as a whole and reflects the willingness of businesses to invest in energy. The progress in investment attractiveness implementation is unfortunately at an early stage and the smallest.

The energy strategy of Ukraine for the period up to 2030 provides the necessary investments in the amount of USD 227 billion for the implementation of the fuel and energy sector development strategic goals until 2030, including the electricity sector (with renewable energy) - USD 98 billion, nuclear energy and the nuclear industry - USD 49 billion, coal industry - USD 10 billion, oil and gas - USD 70 billion (ESU 2030). Meeting such targets is an extremely difficult task and is possible only if deep progress is made in reforming the energy sector and the economy as a whole. It should be noted that in Ukraine's economy the rate of gross fixed capital formation has fluctuated very low over the past ten years - from 12\% to 19\% (SSSU 2020), with the required minimum value of $25 \%$ of GDP. Ukraine's investment climate is not conducive to intensifying investment processes. According to the World Bank's ranking of easy doing business - Doing Business 2019, Ukraine was ranked 71st out of 190 countries (for comparison, Poland $-33^{\text {rd }}$ place, Romania $-52^{\text {nd }}$, the Russian Federation - 31) (WB 2019). In the energy sector important obstacles to attracting investment resources are the lack of relevant markets, significant monopolization of the sector, as well as inconsistencies in the state energy policy. These assessments of Ukraine's energy policy indicate some positive changes in the energy sector, however, reflect contradictions and problems which must be solved with the participation of the state. The imbalance of reforms in the energy sector and the country's economic system remains a fundamental reason for the lack of progress in reforms' implementation.

The need to improve the state energy policy is obvious today due to the rapid changes in world energy (NISD 2018; EPUEI 2019; CGETU 2050), as well as new challenges and threats to national security of Ukraine, which require an appropriate response from the state as a subject of formation and implementation of economic and energy policy. Firstly, we should keep in mind the expected growth of global demand for energy resources by 2035 over $30 \%$, changes in demand for primary energy resources as a result of new technologies and a significant increase in environmental attention, further dominance of oil, gas and coal as a main sources of energy, growth of liquefied natural gas production, rapid growth of consumption of alternative energy sources, development of energy infrastructure and the emergence of new routes for energy supply. In addition, the transformation of Ukraine's economic system will be accompanied by the transformation of the country's energy complex, which will create new challenges in the energy sector.

Given the above trends in global energy development, challenges for Ukraine's security in the energy sector and its desire to join international initiatives aimed at combating climate change and moving towards sustainable development, the country has made a decision to revise the Energy 
Strategy for the period up to 2035 approved in 2017 (DNSDCU 2019). In this regard, the Ukrainian Government has begun to develop the Concept of "green" energy transition of Ukraine until 2050 (CGETU 2050).

The concept is based on modeling options for the transformation of the energy sector over thirty years (up to 2050). Its main goal is to reduce harmful emissions and move towards building an economy that will not have a negative impact on climate change. This task should be implemented by 2070 . The systematic updating of the Concept in accordance with future trends and changes in the world energy system is planned. The concept sets extremely ambitious goals, the implementation of which is impossible without profound institutional changes and improving the quality of economic growth in the near future. However, such a vector of public policy changes its ideology according to the current trends in the energy sector of leading countries and is an important tool for Ukraine's involvement in integration processes at the international level, which expands the opportunities for effective transformations in the energy sector.

\section{Conclusions}

The implementation of an effective energy policy in the industrial model of the economy, which is characterized by significant structural imbalances and energy intensity, is an important component of ensuring the efficiency of macroeconomic transformations, a prerequisite for increasing national competitiveness. The transition to competitive relations in Ukraine's energy sector has created both new opportunities for its development and new challenges. Unfortunately, the slow and contradictory processes of reforming Ukraine's fuel and energy sector throughout the period of its independence did not ensure its effective transformation.

Ukraine's energy policy since the early 1990s has been shaped by difficult economic and political conditions - a significant decline in GDP, a continuous lack of political support for market reforms, politicization of the energy sector, a rapid rise of fuel and energy prices, global economic crises and more. The slow transition to the strategic model of energy policy, its contradictory nature, inconsistency with the main directions of economic policy did not ensure the development of adaptive capabilities of the fuel and energy sector. In the conditions of rapid changes in the world energy sector, the delay in real reforms has leveled even the positive achievements of certain measures in the approaches to energy policy in many developed countries. As a result, the energy sector continues to be an area of escalating threats to the country's energy and economic security.

There are two main factors moving away from the formal and declarative nature of Ukraine's energy policy to its realistic model-namely an international factor associated with Ukraine's extending involvement in international cooperation within the energy sector, Ukraine's international commitments to reform the energy sector towards increasing energy efficiency, green energy, etc., and the crisis factor - as a result of the energy policy of the Russian Federation. 
Today, there is every reason to believe that the role of these factors in the future will remain determining.

The need to improve Ukraine's energy policy is presently obvious. The new energy strategy should contain clear mechanisms for the transition to a climate-neutral economy, which requires justification of a whole range of its areas, coordination of energy and economic policy priorities. The implementation of such tasks in practical terms is complicated by the lack of an appropriate institutional framework, disparities in the structure of the economy and the significant potential for threats to its energy security.

It is impossible to move systematically towards the effective transformation of Ukraine's fuel and energy sector without the completion of privatization processes and a full-fledged transition to competitive fuel and energy markets. Therefore, there is a need for a rational combination of economic and energy policy instruments that would balance the interests of all economic entities.

Underestimation of the manifestation's features of possible effects in the economic sphere due to the implementation of certain instruments of energy policy has been and remains one of the reasons for the low efficiency of the country's energy strategy. The potential instability of the country's economic environment undermines the established values of the energy strategy's target parameters, requiring their systematic adjustment. An important task is to substantiate the sources of investment support for the processes of innovative modernization of the fuel and energy sector and effective mechanisms for their activation, which will attract strategic investors.

\section{References}

AAUEU 2015. Association Agreement between Ukraine, of the one part, and the European Union, the European Atomic Energy Community and their Member States, of the other part (Uhoda pro asotsiatsiyu mizh Ukrayinoyu, z odniyeyi storony, ta Yevropeys'kym Soyuzom, Yevropeys'kym spivtovarystvom $z$ atomnoyi enerhiyi i yikhnimy derzhavamy-chlenamy, $z$ inshoyi storony) (in Ukrainian).

Analytical report 2019. The impact of the nuclear energy complex on the development of Ukraine (Analitychnyy zvit 2019. Vplyv kompleksu yadernoyi enerhetyky na rozvytok Ukrayiny). [Online] https://ukrns. org/images/activity/2019/2019_09_25/ analitychnyzvit.pdf [Accessed: 2020-10-25] (in Ukrainian).

BARANNIK, V. 2016. Environmental component of energy security: new global requirements and tasks for Ukraine (Ekolohichna skladova enerhetychnoyi bezpeky: novi hlobal'ni vymohy ta zavdannya dlya Ukrayiny). [Online] https://niss.gov.ua/sites/default/files/2016-07/ekologichna_skladova-413cf.pdf [Accessed: 2020-10-25] (in Ukrainian).

BASOK, B. and BAZEEv, Y. 2017. Improving the energy efficiency of Ukraine's economy is the mission and main priority of domestic energy development (Povysheniye energoeffektivnosti ekonomiki Ukrainy missiya i osnovnoy prioritet razvitiya otechestvennoy energetiki). Industrial heating technology 39(2), pp. 46-52 (in Russian).

Bobrov, Y. 2013. Energy security of the state (Enerhetychna bezpeka derzhavy). Kyiv: KROK University of Economics and Law, 308 pp. (in Ukrainian).

CGETU 2050. The concept of "green" energy transition of Ukraine until 2050 (Kontseptsiya "zelenoho" enerhetychnoho perekhodu Ukrayiny do 2050 roku) (in Ukrainian).

Denisyuk et al. 2016 - Denisyuk, S., Kotsar, O. and Chernetska, Yu. 2016. Energy efficiency of Ukraine. Best project ideas (Enerhetychna efektyvnist' Ukrayiny. Krashchi proektni ideyi). Project "Professiona- 
lization and stabilization of energy management in Ukraine". Kyiv: KPI them. Igor Sikorsky, 79 pp. (in Ukrainian).

DNSDCU 2019. Decree of the Ukraine's President On the decision of the National Security and Defense Council of Ukraine of December 2, 2019 "On urgent measures to ensure energy security" (Ukaz Prezydenta Ukrayiny Pro rishennya Rady natsional'noyi bezpeky i oborony Ukrayiny vid 2 hrudnya 2019 roku "Pro nevidkladni zakhody shchodo zabezpechennya enerhetychnoyi bezpeky”) №874/2019 (in Ukrainian).

EESU 2018. Energy efficiency system in Ukraine, project for discussion (Systema enerhoefektyvnosti $v$ Ukrayini, proekt dlya obhovorennya) (in Ukrainian).

EPUEI 2019. Economic policy of Ukraine in the field of energy in the context of European integration (Ekonomichna polityka Ukrayiny $v$ haluzi enerhetyky $v$ konteksti yevropeys'koyi intehratsiyi). [Online] https://pnu.ua/sites/default/ files/dissertation/2019/12347/zaverbnyy.pdf [Accessed: 2020-10-25] (in Ukrainian).

ECER 2012. European Commission Energy roadmap 2050. Publications Office of the European Union. [Online] https://ec.europa.eu/energy/sites/ener/files/documents/2012_energy_roadmap_2050_en_0.pdf [Accessed: 2020-10-25].

ESU 2030. Energy strategy of Ukraine for the period up to 2030 (Enerhetychna stratehiya Ukrayiny na period do 2030 roku) (in Ukrainian).

ESU 2035. Energy strategy of Ukraine for the period up to 2035 "Security, energy efficiency, competitiveness" (Enerhetychna stratehiya Ukrayiny na period do 2035 roku "Bezpeka, enerhoefektyvnist', konkurentospromozhnist"') (in Ukrainian).

IEA 2012. Energy Policies Beyond IEA Countries: Ukraine, DOI: 10.1787/9789264187450-en.

KharichKov, S. and Krutyakova, V. 2014. Key guidelines of the innovative model of Ukraine's economy on the basis of sustainable nature management (Klyuchovi oriyentyry innovatsiynoyi modeli ekonomiky Ukrayiny na zasadakh staloho pryrodohospodaryuvannya). Economy: the realities of time 2(12), pp. 175-183 (in Ukrainian).

Kislyy, V. and Trofimenko, N. 2002. Greening enterprise management (Ekologizatsiya upravleniya predpriyatiyem). Sumy: VTD University Book, pp. 232 (in Ukrainian).

Krog, L. and Sperling, K. 2019. A comprehensive framework for strategic energy planning based on Danish and international insights. Energy Strategy Reviews 24, pp. 83-93. [Online] https://www.sciencedirect.com/science/article/pii/S2211467X19300215 [Accessed: 2020-09-10].

KUDRYA, S. 2015. Status and prospects of development of renewable energy in Ukraine (based on the scientific report at the meeting of the Presidium of the NAS of Ukraine on October 7, 2015) (Stan ta perspektyvy rozvytku vidnovlyuvanoyi enerhetyky $v$ Ukrayini (za materialamy naukovoyi dopovidi na zasidanni Prezydiyi NAN Ukrayiny 7 zhovtnya 2015 r)). Bulletin of the National Academy of Sciences of Ukraine 12, pp. 19-26 (in Ukrainian).

LIR, V. 2018. Formation of Ukraine's energy policy in accordance with the global paradigm of sustainable development (Formuvannya enerhetychnoyi polityky Ukrayiny vidpovidno do hlobal'noyi paradyhmy staloho rozvytku). Global and national economic problems 29. [Online] http://global-national.in.ua/ archive/21-2018/35.pdf [Accessed: 2020-09-21] (in Ukrainian).

MeL'NYK, L. 2015. Energy economics (Ekonomika enerhetyky). Sumy: University book, pp. 378 (in Ukrainian).

MEU 2020. Ministry of Energy of Ukraine (Ministerstvo enerhetyky Ukrayiny). [Online] http://mpe.kmu. gov.ua [Accessed: 2020-11-04] (in Ukrainian).

NCSREU 2020. National Commission for State Regulation of Energy and Utilities. (Natsional'na komisiya $z$ derzhavnoho rehulyuvannya enerhetyky ta komunal'nykh posluh). [Online] http://www.nerc.gov.ua [Accessed: 2020-10-25] (in Ukrainian).

NEPU 1996. Resolution of the Verkhovna Rada of Ukraine "On the National Energy Program of Ukraine until 2010”, May 15, 1996, №191/96-VR (Postanova Verkhovnoyi Rady Ukrayiny “Pro Natsional'nu enerhetychnu prohramu Ukrayiny do 2010 roku”, 15 travnya 1996 roku, №191/96-VR) (in Ukrainian). 
NISD 2018. Analytical report to the Annual Address of the Ukraine's President to the Verkhovna Rada of Ukraine "On the Internal and External Situation of Ukraine in 2018" (Analitychna dopovid' do Shchorichnoho Poslannya Prezydenta Ukrayiny do Verkhovnoyi Rady Ukrayiny "Pro vnutrishnye ta zovnishnye stanovyshche Ukrayiny u 2018 rotsi”). Kyiv: NISD, 688 pp. (in Ukrainian).

NPCR of the UES of Ukraine 2018. Review of analytical works of international energy organizations on the state and scenarios of development of the world energy sphere with the forecast of investment in energy efficiency (Ohlyad analitychnykh robit mizhnarodnykh enerhetychnykh orhanizatsiy shchodo stanu ta stsenariyiv rozvytku svitovoyi enerhetychnoyi sfery $z$ prohnozom investuvannya $v$ enerhoefektyvnist'). NPCR of the UES of Ukraine. Kyiv, 6/2018. [Online] https://ua.energy/wp-content/ uploads/2018/06/2.-rozvyt_svit_energet_sfery.pdf [Accessed: 2020-10-25].

OECD 2019. Snapshot of Ukraine's Energy Sector Institutions, Governance and Policy Framework. [Online] https://www.oecd.org/eurasia/competitiveness-programme/eastern-partners/Snapshot-of-Ukraines-Energy-Sector-EN.pdf [Accessed: 2020-10-25].

OECD monitoring 2035. OECD monitoring of Ukraine's energy strategy for the period up to 2035 (Monitorynh OESR enerhetychnoyi stratehiyi Ukrayiny na period do 2035 r.). [Online] https:// www.oecd.org/eurasia/competitiveness-programme/eastern-partners/Monitoring-the-energy-strategy-Ukraine-2035-UKR.pdf [Accessed: 2020-10-25] (in Ukrainian).

PUA 2010. The Protocol of Ukraine's Accession to the Treaty establishing the Energy Community was ratified by the Verkhovna Rada of Ukraine on December 15, 2010 (Protokol pro pryyednannya Ukrayiny do Dohovoru pro zasnuvannya Enerhetychnoho Spivtovarystva ratyfikovano VR Ukrayiny 15 hrudnya 2010 r.) (in Ukrainian).

RPA 2016. Law of Ukraine "On Ratification of the Paris Agreement" (Zakon Ukrayiny "Pro ratyfikatsiyu Paryz'koyi uhody") (in Ukrainian).

SEP 2018. Strategic Energy Plan. Agency for Natural Resources and Energy. [Online] https://www.enecho. meti.go.jp/en/category/others/basic_plan/5th/pdf/strategic_energy_plan.pdf [Accessed: 2020-10-25].

SSSU 2020. State Statistics Service of Ukraine (Derzhavna sluzhba statystyky Ukrayiny). [Online] http:// www.ukrstat.gov.ua [Accessed: 2020-10-25] (in Ukrainian).

SukHodolia, O. 2017. Geopolitical and economic priorities of Ukraine's energy security (Heopolitychni ta ekonomichni priorytety enerhetychnoyi bezpeky Ukrayiny). Strategic panorama 1, pp. 42-45 (in Ukrainian).

Terrados et al. 2010 - Terrados, J., Almonacid, G. and Aguilera, J. 2010. Energy Planning: a Sustainable Approach. Paths to Sustainable Energy. [Online] https://www.researchgate.net/publication/221909774_Energy_Planning_a_Sustainable_Approach.

WB 2019. World Bank Group Flagship Report "Doing Business 2019”. [Online] https://www.doingbusiness.org/content/dam/doingBusiness/media/Annual-Reports/ English/DB2019-report_web-version. pdf [Accessed: 2020-10-25].

Zubets', M. and Panasyuk, B. 2004. Current problems of Ukraine's economy (Aktual'ni problemy ekonomiky Ukrayiny). Kyiv: Agricultural science, pp. 84 (in Ukrainian). 


\section{Polityka energetyczna Ukrainy: analiza i strategia rozwoju}

\section{Streszczenie}

Artykuł porusza problematykę kształtowania się i realizacji polityki energetycznej Ukrainy od początków jej niepodległości do dnia dzisiejszego. Przeanalizowano specyfikę sektora paliwowo-energetycznego gospodarki kraju, główne etapy jego powstawania, uwarunkowania makroekonomiczne oraz problemy jego transformacji. Udowodniono powolne i wzajemnie sprzeczne procesy reformowania kompleksu paliwowo-energetycznego Ukrainy w całym okresie jej niepodległości oraz brak spójności z głównymi kierunkami polityki gospodarczej, co nie zapewniało skutecznej transformacji. Przedstawiono wyniki oceny OECD postępów w realizacji głównych celów Strategii Energetycznej Ukrainy. Wyniki badań wskazują, iż postęp w osiąganiu celów Strategii Energetycznej Ukrainy jest niejednoznaczny, dlatego strategia ta wymaga odpowiedniego dopracowania. Są dwa główne powody odchodzenia od formalnego i deklaratywnego charakteru polityki energetycznej Ukrainy. Pierwszym z nich jest czynnik międzynarodowy, związany z rozszerzaniem zaangażowania Ukrainy we współpracę międzynarodową $\mathrm{w}$ sektorze energetycznym, międzynarodowe zobowiązania Ukrainy do reformy sektora energetycznego w kierunku zwiększenia efektywności energetycznej, zielonej energii itp. Kolejnym jest czynnik kryzysowy, wynikający z polityki energetycznej Federacji Rosyjskiej. Zwrócono uwagę, że rola tych czynników w przyszłości pozostanie decydująca. Udowodniono potrzebę usprawnienia polityki energetycznej Ukrainy, z uwzględnieniem aktualnych trendów rozwoju światowego systemu energetycznego, nowych wyzwań i zagrożeń wynikających z konfrontacji polityczno-wojskowej i energetycznej z Federacją Rosyjską.

SŁowa KLUCzowE: polityka energetyczna, strategia energetyczna, kompleks paliwowo-energetyczny, bezpieczeństwo 
